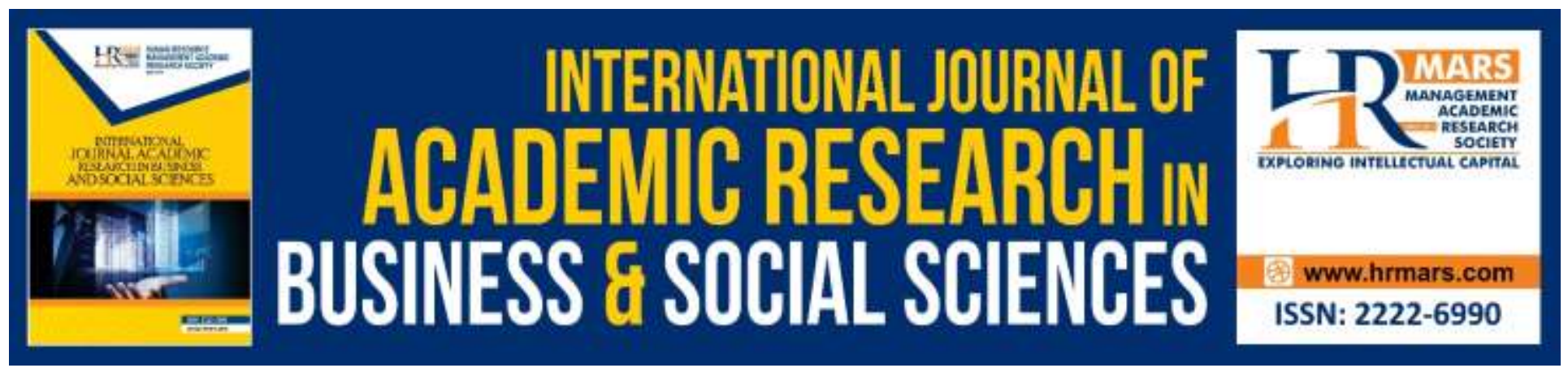

\title{
Financial Technology Inclusion in Islamic Banks: Implication on Shariah Compliance Assurance
}

\author{
Nurfarahin Mohd Haridan, Ahmad Fahmi Sheikh Hassan, and Hatem \\ Abdulaziz Alahmadi
}

To Link this Article: http://dx.doi.org/10.6007/IJARBSS/v10-i14/7361

DOI:10.6007/IJARBSS/v10-i14/7361

Received: 02 April 2020, Revised: 28 May 2020, Accepted: 02 June 2020

Published Online: 29 June 2020

In-Text Citation: (Haridan et al., 2020)

To Cite this Article: Haridan, N. M., Hassan, A. F. S., \& Alahmadi, H. A. (2020). Financial Technology Inclusion in Islamic Banks: Implication on Shariah Compliance Assurance. International Journal of Academic Research in Business and Social Sciences, 10(14), 38-48.

\section{Copyright: (C) 2020 The Author(s)}

Published by Human Resource Management Academic Research Society (www.hrmars.com)

This article is published under the Creative Commons Attribution (CC BY 4.0) license. Anyone may reproduce, distribute, translate and create derivative works of this article (for both commercial and non-commercial purposes), subject to full attribution to the original publication and authors. The full terms of this license may be seen

at: http://creativecommons.org/licences/by/4.0/legalcode

Special Issue: WSTI2018 - Issues and Trends on Education, Science and Technology, 2020, Pg. 38 - 48

Full Terms \& Conditions of access and use can be found at http://hrmars.com/index.php/pages/detail/publication-ethics 


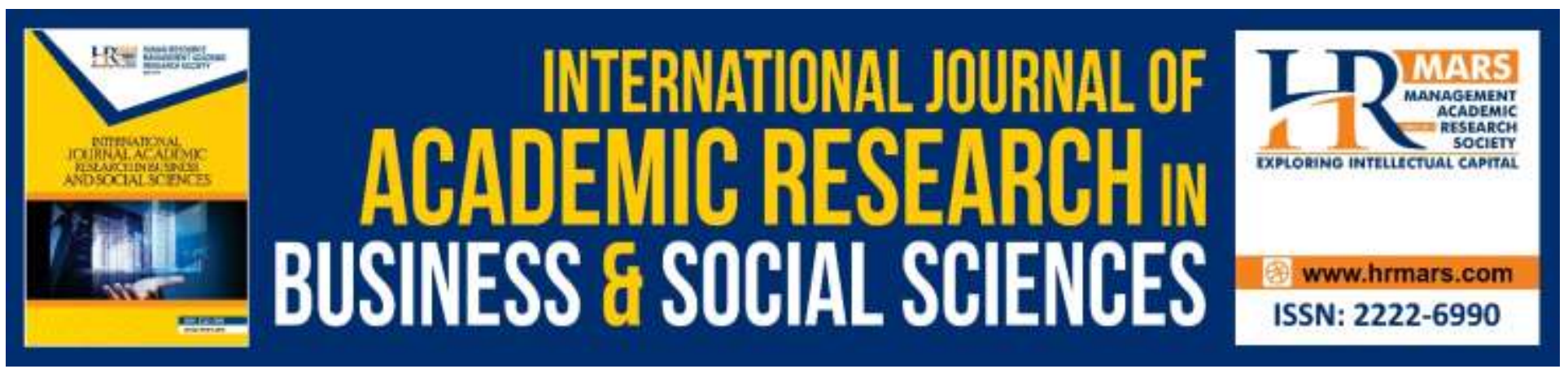

\title{
Financial Technology Inclusion in Islamic Banks: Implication on Shariah Compliance Assurance
}

\author{
Nurfarahin Mohd Haridan ${ }^{1}$, Ahmad Fahmi Sheikh Hassan², and \\ Hatem Abdulaziz Alahmadi ${ }^{3}$ \\ ${ }^{1,2}$ Faculty of Economics and Management, Universiti Putra Malaysia, 43400, Serdang, Malaysia, \\ ${ }^{3}$ Putra Business School, Universiti Putra Malaysia, 43400, Serdang, Malaysia
}

\begin{abstract}
The global technology development has made rapid changes and revolution on the financial services landscape that enforce most banking system including Islamic banks to be more innovative and digitalized. In relation to the technology growth, Islamic banks are now collaborating with Financial Technology (FinTech) companies to grow their market shares. Through critical review of the literatures, we highlight that the inclusion of FinTech may provide important avenues for the Islamic banking industry to offer more innovative financial technology products while being conscious on the morality and Shariah compliant aspects. Besides the beneficial impact and value creation on the application of technology system and information, we also critically highlight several issues on financial risk associated from the technology development and Shariah compliance. We also highlight that it is crucial role for Shariah boards to have the necessary knowledge and skills and to be active with the management of Islamic banks in developing new financial technology products.
\end{abstract}

Keywords: Governance, Shariah Board, Technology Innovation, Digital Finance, Islamic Bank.

\section{Introduction}

The recent success in the tremendous speed of digital finance and technology has a positive impact on the development of financial and banking services in offering a real basis of investment and payment platform and a wider data storage capacity. An analysis presented by Accenture (2016) shows that the value of global Financial Technology (FinTech) investment grew to $\$ 22.3$ billion in 2015, driven by the business deal investment across continental Europe and Asia-Pacific (APAC). Moreover, the expansion of social networks and financial information availability tend to influence financial users' behaviour, preferences, and decisions to use financial services other than traditional banks like FinTech companies (Gomber, Koch \& Siering, 2017). Indeed, FinTech innovation brings a new paradigm to traditional banks for improving their investment infrastructure, utilizing the developments and technology such as social media, big data analytics, and mobile devices (Lee \& Shin, 2018). Not surprisingly, the financial service industry including banks has witnessed the significant evolution of a FinTech-based digital payment system using Internet and digital banking as 
well as electronic fund transfer at the point-of-sale (EFTPOS), automated teller machines (ATM cash dispensers), digital banks (e-commerce), and various others.

The inclusion of FinTech companies in the Islamic finance industry enables the industry to deal with the new dimension of Shariah non-compliance risk worth investigating. Therefore, it is imperative to discuss the way FinTech may potentially integrate its digital platform with the existing Islamic banking products. By critically reviewing several works of literature, we thus highlighted the need for Islamic banks to upgrade their internal governance mechanism, especially the Shariah board, with new skills and knowledge about dealing with FinTech systems and applications. We believe that, by highlighting these two crucial issues, our study may provide an important discussion on the role of the Shariah board in being active with other management and the potential innovative products that Islamic banks may offer through technology applications and digital finance systems. Additionally, we believe our study may shed light on the current use of high technology innovation among Islamic banks to ease access, lower the cost, and enhance quality services, while ensuring the essential values proposed by some scholars on the moral integrity and protection of the sociopolitical environment (see example Archer, Karim \& Al-Deehani, 1998; Belal, Abdelsalam \& Nizamee, 2015; Ullah, Harwood \& Jamali, 2016; Almutairi \& Quttainah, 2017).

In the next section, we provide an overview of FinTech and digital finance in relation to the financial service sector and development. Later, in the following section, we discuss the importance of FinTech inclusion for Shariah compliance and Islamic finance. Next, a review of some important literature to highlight the Shariah and Islamic bank issues pertaining to the emergence of financial technology operation is provided. Finally, we present a summary of FinTech inclusion in the development of Shariah compliance and Islamic bank industry.

\section{Overview of FinTech and Digital Finance}

The technology development brings new phenomena to the financial sector in offering fast and real-time financial basis products with low-cost services, such as digital finance. The terms "FinTech", "e-Finance", and "digital finance" are frequently used to describe the evolution of financial technology change in the financial sector through technology innovation and solutions. Basically, FinTech originates from the words "financial" and "technology" and describes in the modern business a facilitator of financial innovation. Meanwhile, Angelakopoulos \& Mihiotis (2011) identified other benefits of Internet banking as well as the absence of time constraints and geographical limits, cost cutting, the possibility of easy access for disabled people, and an integrated environment for Internet banking transactions. Pikkarainen, Pikkarainen, Karjaluoto, and Pahnila (2004) highlighted that digital development in the financial services may reduce bank branch networks and minimize the human cost of staff. On the other hand, BCBS (2017, pp. 23) discussed the beneficial of financial innovation in expanding access to financial services (financial inclusion), reaching under-served consumers, reducing transaction costs, providing greater transparency with simpler products and clear cost disclosures, providing greater convenience and efficiency, and enabling tighter controls over spending and budgeting. In light of the market growth, the financial technology innovation is found to have increased the quantity of bank lending (Frame, Srinivasan \& Woosley, 2001; Frame \& White, 2014; Berger, Frame \& Miller, 2005), credit supply (Saretto \& Tookes, 2013), and equity fund (Lerner \& Tufano, 2011).

Previous literature has distinguished the element of financial innovation into five different categories: (1) products and services, (2) organizational structures, (3) processes, (i.e., online credit 
application), (4) systems (i.e., blockchain), and (5) business models (i.e., crowdlending) (see for example, Frame \& White, 2014; Alt \& Sachse, 2012; Haddad \& Hornuf, 2016). In light of these differences, Puschmann (2017, pp. 74) summarized FinTech as "incremental or disruptive innovations in the context of the financial services industry induced by IT developments resulting in new intra- or inter-organizational business models, products and services, organizations, and processes and systems". Meanwhile, Gomber et al. (2017) proposed a conceptual framework, called 'The Cube', in structuring digital finance by applying three central dimensions: (i) digital finance business function, (ii) relevant technologies and technological concepts, and (iii) institutions providing a digital finance solution. These three main dimensions highlighted inside The Cube refer to a specific combination of one business function (e.g., digital financing or crowdfunding), with specific use of technology (e.g., big data analytics) invented by FinTech companies. The Cube also provides important features to the FinTech industry for venturing into new business innovation functions and technologies. For example, FinTech as a financial technology innovator may introduce a new online financial credit market and investment, such as online peer-to-peer (P2P) lending, which presents an alternative source for financial transactions that bypasses financial intermediaries by directly connecting borrowers and lenders.

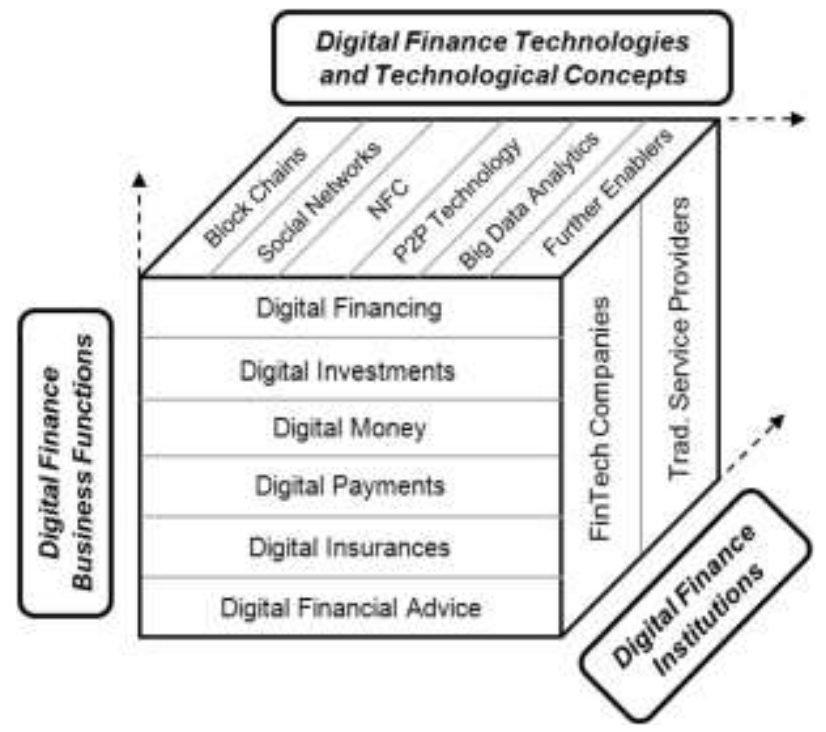

In the next section, we highlight the unique features of Shariah compliance to be put in place in developing a new dimension of Islamic financial products and services with technology innovation invented by FinTech.

\section{Islamic Finance and FinTech}

Traditionally, the Islamic bank is perceived as a financial service institution that provides Muslims with financing facilities based on contacts derived from the Shariah. As an alternative to the conventional financing system, the Islamic banking development is seen as a hallmark to promote and preserve social and economic institutions (Khan \& Mirakhor, 1986; Haniffa \& Hudaib, 2007). In addition, the Islamic banking system is governed by the Shariah principles including risk sharing, individuals' rights, property rights, and the sanctity of contracts (Iqbal, 1997; Zaher \& Hassan, 2001). Meanwhile, El Hawary, Grais \& Iqbal (2004, pp. 5) defined Islamic banking and finance (IBF) as a system that is based on four principles: (1) risk-sharing or concept of equality, (2) materiality or economic value, (3) no exploitation whereby neither party nor the transaction should be exploited, 
and (4) no financing of sinful activities that are banned by the Quran (e.g., alcohol, pork products, gambling, etc.). In addition, the Muslims and Islamic organizations including Islamic banks are made compulsory to pay zakat (alms giving) as purifying the wealth and income of the owner. Also, other Islamic scholar highlighted that the Islamic banking industry operates under the framework of Maqasid al-Shariah (the purpose or the aims of the Shariah) in contrast to the conventional banking system, which operates from the social contract (Dusuki, 2008). As the Maqasid al-Shariah promotes the economic growth and social welfare, it can be argued that the differences between Islamic banking and conventional banking are not just limited to their operations but also include all values that these Islamic banks apply.

By applying The Cube framework discussed earlier, Islamic banks can leverage the products offering by FinTech companies as well as venture new capital funding initiatives under equity financing such as Musyarakah (partnership) or Mudharabah (profit sharing). They can also introduce P2P financing based on risk-sharing concepts that are in line with Shariah principles. On the other hand, collaboration between FinTech companies and Islamic banks should be seen as an opportunity for the former to become part of Islamic banks' internal financial innovative team that ultimately increases the market share of Shariah-compliant banking activities. The importance of FinTech inclusion in the Islamic banking industry also receives the attention of regulators as well as overwhelming support from the government. The IFSB ${ }^{1}$, for example, has highlighted the need for Islamic banks to innovate their business models, products, and processes using recent technology development and large volumes of data available through the Internet (e.g. e-commerce, online banking, and social media) (IFSB, 2017). As Islamic banks venture a new investment of financial technology solution in their traditional banking practices, the particular industry may also facilitate better user interfaces for the mobile management of personal finance as well as lower the cost and perform better service quality (e.g., international remittances or small payments within peer groups) and investment advice (e.g., by robo-advisors) (IFSB, 2017). In relation to this, the regulators in some countries where Islamic banks have high integration with FinTech, such as Malaysia and Singapore, have developed a FinTech Regulatory Sandbox which monitors the technology system and management and encourages experiment of financial technology solutions in a live environment so that it may maintain the overall safety and soundness of the financial system ${ }^{2}$. In addition, Malaysia has taken a new economic venture and initiative by introducing the investment account platform (IAP) as its first Islamic banking-intermediated Internet-based platform underlying the contract of Musyarakah (partnership) (BNM, 2016).

The application and innovation brought by FinTech varies, and the potential it may contribute is wide ranging. Mahomed \& Mohamad (2016), for example, suggested five main core businesses in which Islamic banks may install technology in their financial services: i) banking and lending, ii) payment and fund transfer, iii) investment and wealth management, iv) insurance, and v) blockchain technology. Such financial innovation has the potential to enhance the data screening process and

\footnotetext{
${ }^{1}$ IFSB is an international standard-setting organisation that promotes the soundness and stability of the Islamic financial services industry by issuing a prudential standards and guiding principles for the effective supervision and regulation of the Islamic finance industry.

2 Monetary Authority of Singapore (MAS) and Central Bank of Malaysia (BNM) are the central financial regulatory authorities responsible to promote economic growth and the soundness of financial stability in their respective countries.
} 
monitoring of the borrowers fund (Allen \& Carletti, 2006). As part of the technological innovation, Pittaway, Robertson, Munir, Denyer \& Neely (2004) also highlighted the importance of firms demonstrating business networking behaviour in enabling them to access new markets and technology, pooling sufficient skills, identify technological risk, and speeding up the process and operation. The innovation of technology may also increase the customer autonomy in using the financial services with less time and effort to visit the bank branch. Additionally, the adoption of Internet banking systems in most banking system could result in reducing costs and improving customer service (Lee, 2009; Xue, Hitt, \& Chen, 2011). From the above discussion, we can summarize that the installation of technological advancement provides a new approach to the financial service industry, including Islamic banks in offering more innovative and efficient products, systems, and processes that comply with the Shariah.

\section{Emerging Shariah Issues on Financial Technology Operation in Islamic Banks}

Despite its virtuous character, the governance framework for FinTech is still under early investigation and discussion among academic scholars. The lack of standards and regulation, issues related to data security, and the inferiority of the knowledge and skills involved are the main obstacles to increasing the speed of FinTech integration to Islamic finance. Technically, some challenges and security issues arise when banks offer products that are fully integrated through technology innovation. For example, previous study provides grave concerns on the information asymmetry that occurs in the online P2P as it exposes lenders to high investment risk, which tends to distort their bidding decisions (Chen \& Han, 2012). In order to minimize the risk brought by information asymmetry, Herzenstein, Sonenshein \& Dholakia (2011) suggest full financial disclosure and the initiation of the development of mutual trust between borrowers and lenders, aiming at making the P2P online market lending more efficient. In addition, the operational risk from the online digitalization should also been given attention, as the information accessibility leads to vulnerability of internal control and processes that expose organizations to fraud risk. Another issue with adopting FinTech is related to the high speed of processing transactions, payments, and instructions that often raise an alert flag (see for example Miller, 2015; Avergun \& Kukowski, 2016). Arguably, these risks could potentially result in making the financial contract and system to become uncertain (gharar) as the system hacking and system fault unfairly fails to complete the business transaction thus open a room for fraudsters to take advantage of system inadequacies to perform unauthorized transactions. Recent studies also highlighted that an effective internal control on data security and strong governance could mitigate the operational risk issues arises from the financial technology (Wang and Hsu, 2013; Neifar and Jarboui, 2017). Hence, it is important for FinTech and other Islamic bank players to work together in handling the Shariah non-compliance issues and risk in light of the emerging new financial technology and products. When viewing the structure and framework of Islamic finance, Shariah allows Islamic banks to innovate their banking system, operations, and contract. Whilst the technology solution should comply to all Shariah law and principles, it should uphold the moral integrity concept and protect the socio-political environment as an optimal Islamic finance entity promoted by some scholars (see example Archer et al., 1998; Belal et al., 2015; Ullah et al., 2016; Almutairi \& Quttainah, 2017).

In this regard, FinTech companies must work closely with Shariah boards, as the latter play an integral role in overseeing all Shariah aspects, including the transactions, model and framework, and operations of the industry (see for example Briston \& El-Ashker, 1986; Tomkins \& Karim, 1987; Karim, 
1990a; Karim, 1990b; Banaga et al., 1994; Ghayad, 2008). Generally, the Shariah board members are perceived as individuals with religious and ethical commitment with credible Islamic educational backgrounds and well-respected individuals. The Shariah boards also provide independent Shariah assurance on Islamic bank operations, similar to the role performed by the external auditor. As such, the Shariah boards must ensure that they possess adequate Shariah and Islamic banking knowledge and other professional qualifications in the areas of accounting, auditing, finance, law, technology, and others (see for example Gambling, Karim \& Jones, 1993; Grais \& Pellegrini, 2006a; Ginena, 2014). The appointment of a competent Shariah board will ensure proper governance and professional skepticism by offering adequate and relevant questioning of the responsible managers before issuing any Shariah resolutions. Studies have indicated that higher Shariah compliance roles provided by Shariah boards result in greater monitoring of Shariah compliance-related issues (see for example Farook, Hassan \& Lanis, 2011; Neifar \& Jarboui, 2017; Ajili \& Bouri, 2018). Hence, the active involvement of Shariah boards may facilitate Islamic banks in developing Islamic finance smart contracts and agreements that fulfil Shariah law and other guidelines stipulated by the central banks. For example, Shariah boards may provide advice regarding the management of banks in identifying an adequate technology resolution platform that present less controversy such as the development of smart contracts and agreements from the blockchain innovation and application. Studies have highlighted that the modification on the blockchain system and architecture, i.e., the blockchain management system (BMS), can benefit Islamic banks in performing a better financial system that conforms to Shariah principles (Evans, 2015). Others also argue that the medium of exchange using bitcoin and other cryptocurrency is fixed, thereby eliminating the issue of gharar (uncertainty) and inflation (Muedini, 2018). Yet, the short of talent on Shariah scholars who are well versed in identifying Shariah compliance risk on matters related to financial technology solutions is the main challenge for the development of Islamic financial products and service-based technology. Already the effectiveness of Shariah boards in providing religious compliance assurance has been questioned by scholars. This include criticisms for meeting the profit motive of Islamic banking management's compromising Shariah compliance (Ghayad, 2008; Ahmed, 2011), practicising minimum supervision of Shariah implementation (Garas and Pierce, 2010; Najeeb and Ibrahim, 2014; and Othman and Ameer, 2015) and lack of independence due to over reliance on the role of internal officers (Haridan et al., 2018). Hence, it is important for each individual Islamic bank to take initiatives in building up their capacity and human capital in relation to financial technologies in order to offer newer areas of facilitating on automated Shariah-compliant banking operations.

\section{Conclusions}

The emergence of technology in the financial institution has contributed to the growth of industry and economic development. With reference to "The Cube" discussed earlier, we argue FinTech plays a significant role in being active as a financial technology innovator that provides a new platform of technology investment to the financial services industry. In relation to financial service, the FinTech market penetration in Islamic banks is still in its infancy, hence it needs further investigation on how Islamic banks may innovate their existing products and practices through the integration of FinTech. In this light, Islamic banks act as Islamic financial service providers whose underlying principles regarding its operations and activities are governed by Shariah law. Shariah law permits Islamic banks to invest in any activities and processes that apply new technology innovation and solutions that comply with Shariah principles. In this study, we highlighted several beneficial 
elements of a financial innovation portfolio through Fintech inclusion that allows Islamic banks to offer innovative Islamic financial products and services at low cost, thus delivering better bank services, creating financial transaction flexibility and ease access, and enlarging Islamic market shares.

Despite the benefits of using financial technology application, our critical review highlights that the main challenge faced by the Islamic banking industry with FinTech inclusion is the lack of expertise to handle high-tech financial services and products in Islamic banks. With both technology and Shariah experts, Islamic banks can select a new approach for technology solutions to its existing products and services. We also highlight the need for Shariah boards to upgrade their knowledge and skills that will allow them to be active in developing financial innovation products based on the technology provided by FinTech companies, as their responsibility is to endorse any financial product that complies with the Shariah. Additionally, the new wave brought by FinTech to the Islamic finance study has been limitedly discussed by regulators. Regulators in Islamic jurisdictions need to keep phase with FinTech development, with timely guidelines to welcome the innovation of traditional Islamic financial products and services with new technology advancement offered by FinTech, whilst at the same time maintaining monetary policy that ensures stability in the financial market. Islamic banks need to undertake more extensive research on technology solutions for developing innovative Shariah compliance products that fulfil the needs of society and realize the Maqasid al-Shariah.

\section{Acknowledgements}

The authors are grateful to Universiti Putra Malaysia for supporting this study through Putra Grant Scheme (Project Number: 9632200).

\section{References}

Accenture. (2016). Fintech and the evolving landscape: landing points for the industry. Available at: fintechinnovationlab.com/wp-content/.../05/Fintech_Evolving_Landscape_2016.pdf

Ahmed, H. (2011). Maqasid al-Shari'ah and Islamic financial products: A framework for assessment. ISRA International Journal of Islamic Finance, Vol. 3(1), pp. 149-160.

Ajili, H., and Bouri, A. (2018). Corporate governance quality of Islamic banks: Measurement and effect on financial performance. International Journal of Islamic and Middle Eastern Finance and Management, Vol. 11(3), pp.470-487.

Allen, F., and Carletti, E. (2006). Credit risk transfer and contagion. Journal of Monetary Economics, Vol. 53, pp. 89-111

Almutairi, A. R., and Quttainah, M. A. (2017). Corporate governance: Evidence from Islamic banks. Social Responsibility Journal, Vol. 13(3), pp. 601-624

Alt, R., and Sachse, S. (2012). Banking innovation. In: Gramlich L, Gluchowski P, Horsch A et al (eds) Gabler Bank-Lexikon, 14th edn. Springer Gabler, Wiesbaden, pp 161-162.

Angelakopoulos, G., and Mihiotis, A. (2011).E-banking: challenges and opportunities in the Greek banking sector. Electronic Commerce Research, Vol. 11(3), pp. 297-319.

Archer, S., Karim, R. A. A., and Al-Deehani, T. (1998). Financial contracting, governance structures, and the accounting regulation of Islamic banks: An analysis in terms of agency theory and transaction cost economics. Journal of Management and Governance, Vol. 2, pp. 149-170. 
Avergun, J., and Kukowski, C. (2016), “Complying with AML Laws: challenges for the Fintech Industry", Available at: www.crowdfundinsider.com/2016/04/83845-complying-with-amllawschallenges-for-the-Fintech-industry/ (accessed 21 November 2016).

Banaga, A., Ray, G. H., and Tomkins, C. (1994).External audit and corporate governance in Islamic banks: A joint practitioner-academic research study. Aldershot, Avebury.

BCBS. (2017). Sound Practices: Implications of Fintech Developments for Banks and Bank Supervisors. Basel Committee on Banking Supervision.

Belal, A. R., Abdelsalam, O., and Nizamee, S. S. (2015). Ethical reporting in Islamic bank Bangladesh limited (1983-2010). Journal of Business Ethics, Vol. 129, pp. 766-784.

Berger, A.N., Frame, W. S., and Miller, N. (2005). Credit scoring and the availability, price, and risk of small business credit. Journal of Money, Credit, and Banking, Vol. 37(2), pp. 191-222.

BNM. (2016). Financial Stability and Payment Systems Report 2016. Bank Negara Malaysia.

Briston, R., and El-Ashker, A. (1986). Religious audit: Could it happen here? Accountancy, 98 (1118), 120.

Chen, D., and Han, C. (2012). A comparative study of online P2P lending in the USA and China. Journal of Internet Banking and Commerce, Vol. 17(2), pp. 1-15.

Dusuki, A. W. (2008). Understanding the objectives of Islamic banking: A survey of stakeholders' perspectives. International Journal of Islamic and Middle Eastern Finance and Management, Vol. 1(2), pp. 132-148.

El Hawary, D., Grais, W., and lqbal, Z. (2004). Regulating Islamic financial institutions: The nature of the regulated. World Bank Policy Research Working Paper.

Evans, C. W. (2015). Bitcoin in Islamic Banking and Finance. Journal of Islamic Banking and Finance, Vol. 3, No. 1, pp. 1-11

Farook, S., Hassan, M. K., and Lanis, R. (2011). Determinants of corporate social responsibility disclosure: The case of Islamic banks, Journal of Islamic Accounting and Business Research, Vol. 2(2), pp.114-141.

Frame, W. S., and White, L. J. (2014). Technological change, financial innovation, and diffusion in banking. SSRN Electronic Journal.

Frame, W. S., Srinivasan, A., and Woosley, L. (2001). The effect of credit scoring on small business lending. Journal of Money, Credit, and Banking, Vol. 33(3), pp. 813-825.

Gambling, T., Karim, R. A. A., and Jones, R. (1993). Creditable organizations: Self regulation v. external standard setting in Islamic banks and British charities. Financial Accountability and Management, Vol. 9(3), pp. 195-207.

Garas, S. N., and Pierce, C. (2010). Shari'a supervision of Islamic financial institutions. Journal of Financial Regulation and Compliance, Vol. 18(4), pp. 386-407.

Ghayad, R. (2008). Corporate governance and the global performance of Islamic banks. Humanomics, Vol. 24(3), pp. 207-216.

Ginena, K. (2014). Shariah risk and corporate governance of Islamic banks. Corporate Governance: The International Journal of Business in Society, Vol. 14(1), pp. 86-103.

Gomber, P., Koch, J., and Siering, M. (2017). Digital Finance and FinTech: Current research and future research directions. Journal of Business Economics, Vol. 87, pp. 537-580.

Grais, W., and Pellegrini, M. (2006a). Corporate Governance in Institutions Offering Islamic Financial Services - Issues and Options. World Bank Policy Research Working Paper 4051. 
Haddad, C., and Hornuf, L. (2016). The emergence of the global fintech market: economic and technological determinants. University of Lille \& University of Trier, CESifo Working Paper Series No. 6131, Lille \& Trier.

Haniffa, R. M., and Hudaib, M. (2007). Exploring the ethical identity of Islamic banks via communication in annual reports. Journal of Business Ethics, Vol. 76(1), pp. 97-116.

Haridan, N. F. M., Hassan, A. F. S., and Karbhari, Y. (2018). Governance, religious assurance and Islamic banks: Do Shariah boards efectively serve?, Journal of Management and Governance.

Herzenstein, M., Sonenshein, S., and Dholakia, U. M. (2011). Tell me a good story and I may lend you money: The role of narratives in peer-to-peer lending decisions. Journal of Marketing Research, Vol. 48, pp. 138- 149.

IFSB. (2017). Islamic Financial Services Industry Stability Report 2017. Islamic Financial Service Board.

Iqbal, Z. (1997). Islamic financial systems. Finance \& Development, Vol. 34(2), pp. 42-45.

Karim, R. A. A. (1990a). The independence of religious and external auditors: The case of Islamic banks. Accounting, Auditing \& Accountability Journal, Vol. 3(3), pp. 34-44.

Karim, R. A. A. (1990b). Standard setting for the financial reporting of religious business organisations: The case of Islamic banks. Accounting \& Business Research, Vol. 20(80), pp. 299- 305.

Khan, M. S., and Mirakhor, A. (1986). The framework and practices of Islamic banking. Finance Development 3(September), pp. 32-36.

Lee, I., and Shin, Y. J. (2018). Fintech: Ecosystem, business models, investment decisions, and challenges. Business Horizons, Vol. 61, pp. 35-46.

Lee, M.-C. (2009). Factors influencing the adoption of internet banking: An integration of TAM and TPB with perceived risk and perceived benefit. Electronic Commerce Research and Applications, Vol. 8(3), pp. 130-141.

Lerner, J., and Tufano, P. (2011). The consequences of financial innovation: A counterfactual research agenda. Annual Review of Financial Economics, Vol. 3(1), pp. 41-85.

Mahomed, Z., and Mohamad, S. (2016). Disruptors: Financial innovation and riding the fintech wave. Available at: www.inceif.org/archive/wp.../Bulletin-Vol.2-article-2.pdf

Miller, M. A. (2015), "Faster payments means faster fraud", available at: www.Fintechbusiness.com/ blogs/89-faster-payments-means-faster-fraud (accessed 3 December 2016).

Muedini, F. (2018). The compatibility of cryptocurrencies and Islamic finance. European Journal of Islamic Finance, No. 10.

Najeeb, S. F., and Ibrahim, S. H. M. (2014). Professionalizing the role of Shariah auditors: How Malaysia can generate economic benefits. Pacific-Basin Finance Journal, Vol. 28, pp. 91-109.

Neifar, S., and Jarboui, A. (2017). Corporate governance and operational risk voluntary disclosure: Evidence from Islamic banks. Research in International Business and Finance.

Othman, R., and Ameer, R. (2015). Conceptualizing the duties and roles of auditors in Islamic financial institutions. Humanomics, Vol. 31(2), pp. 201-213.

Pikkarainen, T., Pikkarainen, K., Karjaluoto, H., \& Pahnila, S. (2004). Consumer acceptance of online banking: An extension of the technology acceptance model. Internet Research, Vol. 14(3), pp. 224-235. 
Pittaway, L., Robertson, M., Munir, K., Denyer, D., and Neely, A. (2004). Networking and innovation: a systematic review of the evidence. International Journal of Management Reviews, Vol. 5/6(3\&4), pp. 137-168.

Puschmann, T. (2017). Fintech. Business \& Information Systems Engineering, Vol. 59(1), pp. 69-76. Saretto, A., and Tookes, H. E. (2013). Corporate leverage, debt maturity and credit supply: The role of credit default swaps. Review of Financial Studies, Vol. 26, pp. 1190-1247.

Tomkins, C., and Karim, R. A. A. (1987). The Shari'ah and its implications for Islamic financial analysis: An opportunity to study interactions among society, organization, and accounting. The American Journal of Islamic Social Sciences, Vol. 4(1), pp. 101-115.

Ullah, S., Harwood, I. A., and Jamali, D. (2016). 'Fatwa repositioning': The hidden struggle for Shari'a compliance within Islamic financial institutions. Journal of Business Ethics, pp. 1-23.

Wang, T., and Hsu, C. (2013). Board composition and operational risk events of financial institutions. Journal of Banking and Finance, Vol. 37, pp. 2042-2051.

Xue, M., Hitt, L. M., \& Chen, P. (2011). Determinants and Outcomes of Internet Banking Adoption. Management Science, Vol. 57(2), pp. 291-307.

Zaher, T. S., and Hassan, M. K. (2001). A comparative literature survey of Islamic finance and banking. Financial Markets, Institutions \& Instruments, Vol. 10(4), pp.155-199. 